\title{
Okul Yöneticilerinin Uzaktan Eğitim Döneminde Kullandıkları Çatışma Stratejileri ve Yöntemleri
}

DOI: 10.26466/opus.941774

\author{
$*$ \\ Tuba Aydın Güngör* - Mehtap Yılmaz ** \\ * Dr. Öğr.Üyesi, Artvin Çoruh Üniversitesi, Artvin/Türkiye \\ E-Posta: tuba.gngr@artvin.edu.tr \\ ORCID: $\underline{0000-0002-3356-7826}$ \\ ** Uzm., Milli Eğitim Bakanlığı, Artvin/Türkiye \\ E-Posta: optikdnys@gmail.com \\ ORCID: $\underline{0000-0001-9793-3517}$
}

\begin{abstract}
Öz
Kriz anında önemli olan oluşan durumdan kaçmak ya da kriz durumunu çözüme kavuşturmak değil, kriz çıkmadan çıkmasını önleyebilmek ya da var olan kriz durumunu avantaja dönüştürebilmektir. Krizi tetikleyen faktörler çoğu zaman kendisini önceden belli eder. Kriz yöneticisi bu süreçte olumsuzluğa kapılıp durumu çözüme kavuşturamayabilir. Bununla birlikte başarılı bir şekilde krize yön de verebilir. Önemli olan kriz durumunun olumsuz duygu durumuna dahil olmamaktır. Çă̆daş yönetim anlayışında krizi oluşturabilecek ögelerin önceden belirlenmesi esas alınmıştır. Bu noktadan hareketle, bu çalışmanın amacı tüm dünyada yaşanan Covid-19 pandemisinin meydana getirdiği kriz döneminde okul yöneticilerinin çatışma stratejileri ve yöntemlerini araştırmak ve aynı zamanda yöneticilerin bu süreci nasıl yönettiklerini ortaya koymaktır. Araştırma nitel bir çalışmadır ve yarı yaptlandırılmış görüşme formu kullanılmıştır. Araştırmada fenomenolojik desen kullanılmıştır. Araştırma Artvin ilinde çalışmakta olan 15 okul yöneticisiyle gerçekleştirilmiştir. Verilerin analizinde nitel veri analiz yöntemi olan içerik analizi tercih edilmiştir. Çalışma sonunda okul yöneticilerinin kriz dönemlerinde kullandıkları çatışma yöntemleri, motivasyon yöntemleri nelerdir ortaya konulmuş, kriz zamanlarında yöneticilerin farklı durumlarda nasıl davrandıkları belirlenmeye çalışılmıştır.
\end{abstract}

Anahtar Kelimeler: $\quad$ Kriz yönetimi, okul yöneticileri, Covid-19. 


\title{
The Schools Principal's Methods and Strategies Used in the Distance Education Period
}

\begin{abstract}
The important thing at the time of the crisis is not to escape from the situation or to resolve the crisis situation, but to prevent it from coming out before the crisis emerges or to turn the existing crisis situation into an advantage. The factors that trigger the crisis often predict themselves. The crisis manager may fall into negativity in this process and may not be able to resolve the situation. However, it can also successfully steer the crisis. The important thing is not to get involved in the negative mood of the crisis situation. It is based on the determination of the elements that can create the crisis in the modern management approach. From this point, the aim of this study is to research the schools principal's methods and strategies of conflict solving during the crisis periods and also to reveal how school principals manage the process during the crisis caused by the covid-19 pandemic. This study is a qualitative research and semi- structured interview form was used. Research has been designed as a phenomenological pattern from qualitative research types. The data was analysed with content analysis from qualitative data analysis methods. At the end of the study, the conflict and motivation methods used by school principals in crisis periods were revealed and it was tried to determine how principals behave in different situations during crisis times.
\end{abstract}

Keywords: Crisis management, School principals, Covid-19. 


\section{Giriş}

Örgüt, belli bir amacı gerçekleştirmek için ortak hedef belirlemiş kişilerin bir araya geldiği topluluktur. Örgüt, insanların bazı hedef ve değerler için ortaya koydukları bir anlaşma ve iş birliğidir. Örgüt; iş bölümü, işlevlerin belirlenmesi, yetki ile sorumluluğun basamaklaştırılması yoluyla açıkça belirlenmiş, ortak bir amacın gerçekleştirilmesi için kişilerin faaliyetlerinin akılcı bir biçimde koordine edilmesi sürecini içerir. Örgüt olabilmek için iletişim içerisinde olmak ve ortak amaçları gerçekleştirme isteği olmalıdır (Aydın, 1994). Ortak hedefleri gerçekleştirmek ve sistematik bir şekilde ilerleyebilmek için örgütün yönetimini sağlayan iyi bir lidere ihtiyaç vardır.

Örgütler belirlemiş oldukları hedeflere ulaşmak isterken bazen istenmedik ve beklenmedik olumsuzluklarla karşılaşabilmektedir. Böyle zamanlarda örgütün var olan stratejisi yetersiz kalabilir ve yeni bir yol izlemek üzere çalışmalar yapılabilir. Kimi zaman örgüt içerisinde ortaya çıkan krizler de örgütün işleyişinin sendeye uğramasına ve günlük rutinin bozulmasına sebep olur. Yaşanan kriz anında güçlü, kararlı ve etkili liderlik gerekmektedir. Lider kendinden emin olmalı ve var olan kriz durumunu yeni stratejiler belirleyerek daha güçlü bir şekilde ortadan kaldırmayı sağlayabilmelidir.

Yöneticilerin liderlik özellik ve yeterliliklerine en çok ihtiyaç duyulan zaman örgüt içerisinde çıkan kriz zamanıdır. Çünkü iyi bir yönetici kriz sürecini kendi kontrolünde başarılı bir şekilde atlatmak durumundadır. Bu da yöneticinin liderlik, bilgi ve becerisi, deneyim ve kararlılık gibi özelliklerine bağlıdır. Yöneticilik, örgütte problem çözme sürecidir diyebiliriz. Buna bağlı olarak ta lider yöneticiler örgüt için kritik zamanlarda ve kriz dönemlerinde ortaya çıkarlar (Peker ve Aytürk, 2000).

Diğer örgütler gibi eğitim örgütlerinde de zaman zaman krizler yaşanır. İdareciler okulun rutini dışında, ortaya çıan krizlere de koşuşturmaktadırlar (Altun, 2001, s.464). Kriz durumunu yetkin bir şekilde yönetebilmek için, öncesinde hazırlıklı olmak gerekmektedir. Kriz yönetimi, oluşabilecek kriz durumların tespit etmeli ve bu durumlarla nasıl bahşedileceğini belirlemelidir. Örgütün olası kriz durumlarına belli oranda bütçeden pay ayırması da gerekmektedir. Kriz anında bilgi, gerekli önlemler ve kararlılık krizle başa çıkma da önemli unsurlardandır.

Kriz anında önemli olan oluşan durumdan kaçmak ya da kriz durumunu çözüme kavuşturmak değil, kriz çıkmadan çıkmasını önleyebilmek ya da var 
olan kriz durumunu avantaja dönüştürebilmektir. Krizi tetikleyen faktörler çoğu zaman kendisini önceden belli eder. Kriz yöneticisi bu süreçte olumsuzluğa kapılıp durumu çözüme kavuşturamayabilir. Bununla birlikte başarılı bir şekilde krize yön de verebilir. Önemli olan kriz durumunun olumsuz duygu durumuna dahil olmamaktır. Çağdaş yönetim anlayışında krizi oluşturabilecek ögelerin önceden belirlenmesi esas alınmıştır. Fakat, önceden tahmin edilemeyen, örgütün kontrolünde olmayan çevresel faktörlerin etkisiyle ortaya çıkacak; siyasi, sosyal, doğal afetler gibi sebepler de olabilir. Bu sebeplerle ortaya çıkacak olan kriz durumuna idari önlemleri alabilmek ve bu önlemleri uygulayabilmek oldukça önemlidir (Peker ve Aytürk, 2000, s.385-386).

Örgütsel çatışma ast-üst çatışması, eşit statüde ki insanların çatışması, bölümler arası çatışma ve dış etkenlerden kaynaklı çatışmalardır. Örgütsel çatışmaları ortaya koyan farklı yaklaşımlar vardır; geleneksel görüş, çatışmanın kötü bir durum olduğunu savunmuştur. Bu yüzden de çatışmanın mutlaka engellenmesi gerektiğini savunmuşlardır. Davranışsal görüş, çatışmanın doğal olduğunu savunmuştur ve çatışmanın örgüte faydasının olacağı taraflarında olabileceğini savunmuştur. Etkileşimci görüş ise çatışmayı kabul etmiştir. Etkileşimci yaklaşım durağan bir örgüt yerine üyelerin kendini yenileyebilmesi açısından çatışmaya teşvik etmektedir (Genç, 2012).

Örgütsel çatışma yönetimi çatışmaya bakış açısı yönetim anlayışlarından etkilenir. Geleneksel yönetim yaklaşımı, çatışmadan yıkıcı niteliği gereği kaçmak isteyen anlayışı savunur. Bu yaklaşım çatışmanın yönetimi değil çözüm üzerinde durur. Çağdaş yaklaşım ise çatışmayı olan hatta kaçınılmaz olarak görür. Çağdaş yaklaşım çatışmayı sonuçlarına göre fonksiyonel ve bir fonksiyonel olarak ikiye ayırır. Bu görüş gereği olarak da çatışmanın çözülmesi değil yönetilmesi kavramı kullanılır. Çatışmaların çözümünde farklı yöntemler uygulanabilir. Ancak hangi çatışmada hangi yöntemin uygulanacağını çatışmanın iyi analiz edilmesini gerektirir. Çatışmanın çözümü için öncelikle çatışmaya neden olan faktörlerin tespit edilmesi, tanının iyi konulması gerekir (Genç, 2012).

Çin' in Vuhan kentinden 29 Aralık 2019 tarihinde görüldüğü bildirilen, zatürreye ve üst solunum yolları enfeksiyonlarına bilinmedik bir şekilde sebep olan ve ölümle sonuçlanan vakalara sebep olduğu belirtilen virüs Dünya Sağlık Örgütü Tarafından Covid-19 olarak adlandırılmış ve tüm dünyaya 
duyurulmuştur. Ülkemizde ise 2020 yılının mart ayı ortasında ortaya çıkmış ve çeşitli alanlarda krizlere sebep olmuştur.

Okul yöneticilerinin, Covid-19 pandemi sürecinde ortaya çıabilecek; veli, öğrenci, öğretmen üçlüsü arasındaki krizi yönetmekle birlikte eğitimöğretimin aynı şekilde devam etmesini sağlayabilecek önlemler alması gerekmektedir. Tüm dünyayla birlikte etkileyen bu salgının ortaya çıkardığı krizi yönetebilmek yine lider yöneticileri ortaya çıkarmaktadır. Okul yöneticisi kontrolü elinde tutmalı ve muhtemel krizi sağlıklı bir şekilde yönetebilmelidir. Gerek öğrenci motivasyonunun gerek öğretmen ve veli motivasyonunun yüksek tutulması için elinden geleni yapmalı iyi bir yol gösterici olmalıdır.

\section{Araştırmanın Amacı}

Kriz dönemlerinde (Covid-19 pandemi) okul yöneticilerinin çatışma yönetim strateji ve yöntemlerinin araştırılarak ortaya çıkarılması bu çalışmanın amacını oluşturmaktadır.

\section{Araştırmanın Yöntemi}

Araştırmada okul yöneticilerinin Covid-19 pandemi sürecinde meydana gelen veya gelebilecek çatışma ve krizlere karşı kullandıkları yöntem ve stratejiler araştırılmıştır. Çalışmada küçük gruplarda araştırmanın derinlemesine ve araştırmacıya ayrıntılı perspektif sağlaması nedeniyle nitel araştırma yöntemi kullanılmıştır. Nitel araştırma gözlem, görüşme ve doküman analizi gibi nitel veri toplama yöntemlerinin kullanıldığı, algıların doğal ortamda gerçekçi ve bütüncül bir biçimde ortaya konmasına yönelik bir sürecin izlendiği araştırma türüdür. Aynı zamanda nitel araştırma türlerinden biri olan Olgu bilim (fenomonolojik) desenden faydalanılmıştır. fenomonolojik desen esasen ne olduğunu farkında olduğumuz ancak ayrıntılı şekilde bilmediğimiz olgulara odaklanır (Yıldırım ve Şimşek, 2011). Fenomonolojik desen, bireylerin kendi bakış açılarına göre algı ve deneyimlerini ön plana çıkarmayı amaçlayan bir nitel araştırma desenidir (Ersoy, 2016). Bu desende çalışma grubuna dahil olan katılımciların doğrudan deneyimlere sahip olması önemli olarak görülmektedir (Patton, 2014, s.104). 


\section{Çalışma Grubu}

Araştırmanın çalışma grubunu Artvin ilinde görev yapan 15 okul yöneticisi oluşturmaktadır. Maksimum çeşitlilik sağlamak adına ortaöğretim ve lise kademelerinden yöneticiler seçilmiştir. Nitel verileri toplamak için görüşmeler yapılmıştır.

Tablo 1. Okul Yöneticilerine ait Demografik Bilgiler

\begin{tabular}{lll}
\hline Değişken & Grup & f \\
\hline Cinsiyet & Kadın & 1 \\
& Erkek & 14 \\
Ünvan & Müdür & 10 \\
& Müdür Yard. & 5 \\
\multirow{2}{*}{ Kıdem } & $5-10$ & 8 \\
& $10-15$ & 7 \\
\hline
\end{tabular}

Tablo 1 incelendiğinde araştırmaya dahil olan okul yöneticilerinin 1 tanesinin kadın, 14'ünün erkek; 10'unun müdür 5'inin müdür yardımcısı; kıdem olarak da 8 'inin beş ila 10 yıllık 7 sinin de 10 ila 15 yıllık kıdemlerinin olduğu görülmektedir.

\section{Verileri Toplama Aracı}

Bu araştırma için Artvin Çoruh Üniversitesi Etik Kurulundan 12426 etik kurul numaralı etik kurul izni alınmıştır. Görüşme soruları araştırmacılar tarafından hazırlanmış olup görüşmeler öncesinde okul yöneticilerine konu ile alakalı genel bilgi verilmiştir. Görüşme formunun kapsam geçerliği için de alanında uzman akademisyenlerin görüşleri alındıktan sonra hazır hale getirilmiştir. Araştırmacılar tarafından hazırlanan yarı yapılandırılmış görüşme formu kullanılarak veriler toplanmıştır.Veriler Ekim, Kasım ve Aralık aylarında toplanmıştır.15 okul yöneticisiyle pandemi ve karantina sebeplerinden dolayı sesli ve görüntülü görüşmeler yapılmış akabinde mail ve whatsapp yoluyla sorular ulaştırılıp dönütler alınmış ve veriler yazıya dökülmüştür.

Araştırmanın geçerlik ve güvenirliliği için görüşmeler aynı araştırmacı tarafından yapılmıştır. Katılımcılardan elde edilen veriler araştırmacılar tarafından incelenmiş ve görüşme öncesinde yapılmış olan literatür taraması ile ilişkilendirilerek tema ve kodlar belirlenmiştir. 


\section{Verilerin Analizi}

Veriler analiz edilirken okul yöneticilerinin görüşleri grup ve kategorilere ayrılmıştır. Bu analiz, çalışma ile alakalı genel bir çerçeve oluşturma, bulguların tanımlanması ve yorumlanması aşamalarından oluşmaktadır. Çalışmada bu aşamalara dikkat edilmiş ve yöneticilerin görüşleri belli çerçevede incelenmiştir. Yarı yapılandırılmış görüşme formu kullanılarak elde edilen veriler içerik analizi tekniği ile analiz edilmeye ve yorumlanmaya çalışılmıştır. İçerik analizinde yapılan temel işlem, birbirine benzeyen verileri belirli kavramlar ve temalar çerçevesinde bir araya getirip okuyanların anlayacakları biçimde düzenleyip yorumlamaktır. Aynı zamanda içerik analizi yapılırken fikir, konu veya kavramları belirtmek için alıntı da kullanılabilir (Yıldırım ve Şimşek, 2006, s.39) Formda yer alan sorular göz önüne alınarak temalar ve kodlar belirlenmiştir. Temalar ve kodlar arasındaki ilişki kontrol edilmiş ve bütünlük sağlanmaya çalışılmıştır. Çalışmada katılımcılar $\mathrm{K} 1, \mathrm{~K} 2, \mathrm{~K} 3 \ldots .$. Şeklinde kodlanmıştır.

\section{Verilerin Geçerlik ve Güvenirliği}

Araştırmanın geçerliği için görüşmeler aynı araştırmacı tarafından yapılmış; görüşme verileri katılımcılarla paylaşılıp katılımcı teyidi alınmış; görüşmelerde katılımcılardan elde edilen veriler araştırmacılar tarafından incelenip düzenlenmiş; düzenlemenin ardından görüşmeler öncesinde yapılan literatür taraması dikkate alınarak tema ve kodlar belirlenmiş; farklı özelliklere sahip veri kaynaklarıyla görüşmeler yapılmıştır (Yıldırım ve Şimşek, 2013).

Araştırmanın güvenirliği için ise görüşmelerde elde edilen sesli kayıtlar ve videolar yorum yapılmadan ve eksiksiz yazılarak düzenlenmiş ve bu verilerin olabildiğince fazlası çalışmada verilmeye çalışılmış, görüşme metinleri katılımclarla paylaşılmış olup yanlışsız ve eksiksiz olduğu katılımcılar tarafından doğrulanmıştır (Yıldırım ve Şimşek, 2013).Ortaya çıkan temaların altında yer alan verilerin anlamlı bir bütün oluşturması (iç tutarlılık), daha sonra kendi aralarında bir bütün oluşturabilmesi (dış tutarlılık) için iki akademisyenden görüş alınmış ve gereken yerlerde düzenlemeler yapılmıştır.

\section{Bulgular}


Araştırmanın bu bölümünde toplanan veriler içerik analizine tabi tutulmuş ve yorumlanmaya çalışılmıştır.

\section{Birinci Temaya İlişkin Bulgular}

Tablo 2. Okulunuzda oluşabilecek bir kriz anında hangi (ne tür) çatışma çz̈zme yöntemleri kullanirsiniz?

\begin{tabular}{|c|c|c|c|}
\hline Tema & Katılımclar & Kod & $\mathbf{n}$ \\
\hline $\begin{array}{l}\text { KRİZ ANINDA } \\
\text { PROBLEM } \\
\text { ÇÖZME }\end{array}$ & $\begin{array}{l}\text { "Oluşan krizlerde ve yaşanan çatışmalarda, so- } \\
\text { runun türüne göre birçok yöntemi kullanıyoruz } \\
\text { ancak en çok kullandığımız yöntem; sorun } \\
\text { çözme yaklaşımı ve iş birliği yöntemi } \\
\text { olmakta”k2 } \\
\text { “Okul müdürü olarak birçok ödüllendirme } \\
\text { yöntemini yapamıyoruz. Daha çok } \\
\text { kullandığım, övgü ve yapıcı eleştiri, daha fazla } \\
\text { yetki ve ödül teklif etme"k3 } \\
\text { "Kriz anında sorun çözme yaklaşımı kullanarak } \\
\text { sorunu ortadan kaldırmaya çalışırım. Sorun } \\
\text { anında yapıcı yaklaşımlar daha olumlu sonuç } \\
\text { verir"k5 }\end{array}$ & $\begin{array}{l}\text { İŞ BİRLİĞİ } \\
\text { SORUN ÇÖZME }\end{array}$ & 12 \\
\hline $\begin{array}{l}\text { KRİZ ANINDA } \\
\text { PROBLEM } \\
\text { ÇÖZME }\end{array}$ & $\begin{array}{l}\text { "Ben okulumda bir çatışma yaşandığında yu- } \\
\text { muşatma veya arabulma yöntemlerini } \\
\text { kullanırım. Çünkü kurum kültürü açısından } \\
\text { faydalı görürüm"k11 } \\
\text { "Çatışmaları çözerken her zaman yumuşatma } \\
\text { ve arabulma yöntemi kullanırım"k15 }\end{array}$ & $\begin{array}{l}\text { YAPICI } \\
\text { YAKLAŞIM } \\
\text { ARABULUCULUK }\end{array}$ & 2 \\
\hline $\begin{array}{l}\text { KRİZ ANINDA } \\
\text { PROBLEM } \\
\text { ÇÖZME }\end{array}$ & $\begin{array}{l}\text { "Okullarımızda her türlü kriz oluşabilir bu çok } \\
\text { normal bir süreçtir. Krizin üstesinden gele- } \\
\text { bilmek için bazen güç ve otorite yaklaşımı bazen } \\
\text { de dondurma yaklaşımını kullanırım. Sular du- } \\
\text { ruluncaya kadar bekler yumuşama } \\
\text { beklerim"K12 }\end{array}$ & $\begin{array}{l}\text { GÜÇ } \quad \text { VE } \quad \text { OTORITE } \\
\text { KULLANIMI (CEZA) }\end{array}$ & 1 \\
\hline
\end{tabular}

Tablo 2 de 1.soruda okul yöneticilerinin Covid-19 döneminde ortaya çıan çatışmalarda hangi yöntemi kullanmayı tercih ettikleri görülmektedir. Görüşme yapılan katılımcıların çoğunun iş birliği ve sorun çözme yaklaşımını tercih ettikleri görülmektedir.

"Probleme müdahale ederken sorun çözme yaklaşımını uygulamak her zaman olumlu sonuçlar vermiştir bu nedenle onu kullanırım"; "Sorun çözme, iş birliği yöntemlerini kullanırım" K1, K4, K6, K7, K8, K9, K10, K13, K14 
Yine aynı soruda bazı katılımcılar "Ben okulumda bir çatışma yaşandığında yumuşatma veya arabulma yöntemlerini kullanırım. Çünkü kurum kültürü açısından faydalı görürüm"K11 ifadesiyle arabulma yöntemini tercih ettiğini belirtmiştir.

Sadece bir yönetici “Okullarımızda her türlü kriz oluşabilir bu çok normal bir süreçtir. Krizin üstesinden gelebilmek için bazen güç ve otorite yaklaşımı bazen de dondurma yaklaşımını kullanırım. Sular duruluncaya kadar bekler yumuşama beklerim" şeklinde görüşünü bildirmiştir.

\section{İkinci Temaya İlişkin Bulgular}

Tablo 3. Çalışma ortamınıdda hangi motivasyon yöntemlerini kullanırsınız?

\begin{tabular}{|c|c|c|c|}
\hline Tema & Katılımcilar & Kod & $\mathrm{n}$ \\
\hline $\begin{array}{l}\text { MOTIVASYON } \\
\text { ARAÇLARI }\end{array}$ & $\begin{array}{l}\text { "Motivasyon yöntemlerinden "ücret, prim, ödül, } \\
\text { terfi", bakanlığın yönetmeliklerle belirlediği, belli } \\
\text { kriterlere bağlı olan motivasyon kaynakları olarak } \\
\text { kriterleri karşlayanlara uygulanmaktadır. } \\
\text { Bununla beraber kurum olarak kullandığımız mo- } \\
\text { tivasyon yöntemleri çoğunlukla; koşulların } \\
\text { iyileştirilmesi ve övgü ve yapıcı eleştiri" K2 } \\
\text { "Okul müdürü olarak birçok ödüllendirme yönt- } \\
\text { emini yapamıyoruz. Daha çok kullandığım, övgü } \\
\text { ve yapıcı eleştiri, daha fazla yetki ve ödül teklif } \\
\text { etme"K3 } \\
\text { "Kurumumda motivasyon artırmak için ödül ve } \\
\text { övgü yöntemini kullanırım ancak bizler müdür } \\
\text { olarak para ödülü veremediğimizden daha çok } \\
\text { manevi ödül kullanırı"'K10 }\end{array}$ & $\begin{array}{l}\text { ÖVGÜ } \\
\text { YAPICI }\end{array}$ & 10 \\
\hline $\begin{array}{l}\text { MOTIVASYON } \\
\text { ARAÇLARI }\end{array}$ & $\begin{array}{l}\text { "Motivasyon yöntemi olarak çalışma koşullarının } \\
\text { iyileştirilmesi tercihimdir"K7 } \\
\text { "Eğitim kurumu olarak çalışanlarımızın motivasy- } \\
\text { onlarını artırmak için moral vermeyi ve önem ve } \\
\text { değer verme yöntemini kullanırım çünkü insan } \\
\text { olarak çalışanları değerli olduklarını göstermek } \\
\text { önemlidir"K11 }\end{array}$ & $\begin{array}{l}\text { ÇALIŞMA ŞARTLARINDA } \\
\text { İYILEŞTİRME } \\
\text { MORAL }\end{array}$ & 3 \\
\hline $\begin{array}{l}\text { MOTIVASYON } \\
\text { ARAÇLARI }\end{array}$ & $\begin{array}{l}\text { "Örgüt için motivasyon çok önemli bir kavram } \\
\text { olduğundan öğretmenlerimin ve diğer çalışan- } \\
\text { larımın motivasyonların diri tutmak için sosyal } \\
\text { etkinlikler düzenlerim mesela piknik yapma } \\
\text { geziye çkmak gibi"K13 }\end{array}$ & $\begin{array}{lr}\text { SOSYAL } & \text { ETKINNLIK } \\
\text { DÜZENLEME } & \text { (GEZI- } \\
\text { PİNIK- YEMEK) } & \end{array}$ & 2 \\
\hline
\end{tabular}

Tablo 3 incelendiğinde kriz zamanlarında kullanılan motivasyon araçlarına bakıldığında çoğu okul yöneticisinin çalışanlarına ve öğrencilerine karşı yapıcı eleştiride bulunduklarını hatta övgü yoluyla onları motive etmeye çalıştıkları görülmektedir. Hatta katılımcı müdürlerden bir tanesi şu görüşünü şu şekilde ifade etmiştir "Motivasyon yöntemlerinden "ücret, 
prim, ödül, terfi", bakanlığın yönetmeliklerle belirlediği, belli kriterlere bağlı olan motivasyon kaynakları olarak kriterleri karşılayanlara uygulanmaktadır. Bununla beraber kurum olarak kullandığımız motivasyon yöntemleri çoğunlukla koşulların iyileştirilmesi ve övgü ve yapıcı eleştiri" dir. K2

Aynı şekilde bir yönetici de "Okul müdürü olarak birçok ödüllendirme yöntemini yapamıyoruz. Daha çok kullandığım, övgü ve yapıcı eleştiri, daha fazla yetki ve ödül teklif etme" K3 şeklinde görüşünü ifade etmiştir. Bazı yöneticilerde "motivasyon aracı olarak moral verme, sosyal etkinlik düzenleme gibi aktiviteler planlarız" K13 Ancak sosyal etkinlik pandemi sebebiyle gezi gözlem olarak değil de online olarak, söyleşi, sohbet, müzik dinletisi şeklinde gerçekleştirilebilir diye ifade edilmiştir. Çalışma şartlarını iyileştirme olarak ta bir yönetici görüşünü şöyle ifade etmiştir "Motivasyon aracı olarak çalışma koşullarını iyileştirmeye çalışırım örneğin herkesi mutlu edecek bir ders programı hazırlamak gibi"K12

Bir başka katılımcı da "Çalışan bireyleri analiz edebildiğim kadar analiz eder, motivasyon yöntemini o kişinin özelliğine uygun olarak uygularım. Çalışanların her biri farklı kişilikte olduğundan uygulanan yöntemin de farklı olması gerektiği kanaatindeyim" şeklinde bir diğeri de "Eğitim kurumu olarak çalışanlarımızın motivasyonlarını artırmak için moral vermeyi ve önem ve değer verme yöntemini kullanırım çünkü insan olarak çalışanları değerli olduklarını göstermek önemlidir" şeklinde görüşlerini ifade etmiştir. 


\section{Üçüncü Temaya İlişkin Bulgular}

Tablo 4. okullarda öğrencilerin ruh sağlığın korumak için destek ve hastalık geçiren öğrencilere karşı olan önyargı ile mücadele

\begin{tabular}{|c|c|c|}
\hline Tema & Katılımcılar & Kod \\
\hline $\begin{array}{l}\text { PANDEMİ } \\
\text { BİTIMINDE OKULA } \\
\text { UYUM VE ADAPTA- } \\
\text { SYON }\end{array}$ & $\begin{array}{l}\text { “Okul rehber öğretmeni ve sınıf rehber öğretmeni- } \\
\text { yle beraber öğrencilere bu koşulların geçeceğini sa- } \\
\text { kin olmalarını ve diğer arkadaşlarına karşı önyargılı } \\
\text { olmamalarını anlatır onları bilgilendiririm” K15 } \\
\text { “Varsa ilimizdeki ergen ve ruh sağlığı doktorundan } \\
\text { yardım alarak rehber öğretmenimizin de desteğiyle } \\
\text { olayın üstesinden gelmeye çalışırım”K13 } \\
\text { "Her bir öğretmenin online derslerde öğrencilere } \\
\text { motive edici, kaygıyı azaltıcı, başarıya odaklanma } \\
\text { ve sağlığın korunması konusunda konuşma, sohbet } \\
\text { etmelerini sağlarım. Çok özel problemlerde rehber- } \\
\text { lik servisi, okul idaresi ve psikiyatri desteğini } \\
\text { alırım”K9 }\end{array}$ & $\begin{array}{l}\text { REHBERLIK SERVISİ } \\
\text { YETKIN } \\
\text { KIŞiLERIN } \\
\text { SAĞLIKÇILARIN } \\
\text { DESTEĞINİ ALMAK }\end{array}$ \\
\hline $\begin{array}{l}\text { PANDEMI } \\
\text { BİTIMINDE OKULA } \\
\text { UYUM VE ADAPTA- } \\
\text { SYON }\end{array}$ & $\begin{array}{l}\text { "Ben okulumda bir çatışma yaşandığında yu- } \\
\text { muşatma veya arabulma yöntemlerini kullanırım. } \\
\text { Çünkü kurum kültürü açısından faydalı } \\
\text { görürüm"k11 } \\
\text { “Çatışmaları çözerken her zaman yumuşatma ve } \\
\text { arabulma yöntemi kullanırım"k15 }\end{array}$ & $\begin{array}{l}\text { OYUN } \\
\text { MORAL VE } \\
\text { MOTIVASYON AR- } \\
\text { TIRICI ETKINLIKLER }\end{array}$ \\
\hline $\begin{array}{l}\text { PANDEMİ } \\
\text { BİTIMIINDE OKULA } \\
\text { UYUM VE ADAPTA- } \\
\text { SYON }\end{array}$ & $\begin{array}{l}\text { "Hayatımızda her zaman buna benzer olumsuz } \\
\text { olaylar yaşayabileceğimizi anlatır, bu tür } \\
\text { olumsuzluklarla nasıl başa çıkabileceğimizi an- } \\
\text { latırım. Hastalık geçirenlere karşı önyargıyı bilimsel } \\
\text { açılamalarla ortadan kaldırmayı amaçlarım"K7 }\end{array}$ & $\begin{array}{l}\text { BİLIMSEL AÇIKLAMA } \\
\text { PAYLAŞIMLARI }\end{array}$ \\
\hline
\end{tabular}

Tablo 4 incelendiğinde pandemi süreci sanıldığının aksine çok uzun bir süre devam etmiş hatta hala devam etmektedir. Bu kadar uzun süre okuldan uzak kalan öğrencileri tekrar okula adapte etmek uyum göstermelerini sağlamak zorlu bir süreç olacaktır. Öğrencilerin ruh sağllı̆ına yönelik çalışmalar doğrultusunda okul yöneticilerinin çoğunluğu okul rehberlik servisinden ve yetkili sağlık çalışanlarından destek alacaklarını ifade etmişlerdir. Bazı katılımclar da tercihlerini “Uzun süre eğitim öğretimden uzak kalan öğrencilere moral ve motivasyonlarını artırıcı çalışmalar yapmamız gerekir. Örneğin alanında uzman kişiler tarafından konferans, müzik şöleni, sosyal kültürel faaliyetlerle (online olarak) öğrencilere destek olmalıyız" Ruh sağlığı bozulan öğrencilerimizin yanında olduğumuzu hissettirmeliyiz" K8 şeklinde bildirmişlerdir.

Azınlıkta kalan birkaç yönetici de "hayatımızda her zaman buna benzer olumsuz olaylar yaşayabileceğimizi ve bu tür olumsuzluklarla nasıl başa 
çıkabileceğimizi anlatmak ve hastalık geçirenlere karşı önyargıyı bilimsel açıklamalarla ortadan kaldırmayı amaçlarım” K7 şeklinde fikrini beyan etmiştir.

\section{Dördüncü Temaya İlişkin Bulgular}

Tablo 5. Uzaktan eğitim sürecinde internet ă̆ı-tablet-telefonu olmayan öğrenciler ile iligili ortaya çıkan krize

\begin{tabular}{|c|c|c|c|}
\hline Tema & Katılımcılar & kod & $\mathbf{n}$ \\
\hline $\begin{array}{l}\text { UZAKTAN } \\
\text { EĞITIMIME } \\
\text { KATILIM } \\
\text { PROBLEM- } \\
\text { LER }\end{array}$ & $\begin{array}{l}\text { "Öğrencileri eba destek noktasına yönlendirdik. Fiziksel engeli } \\
\text { sebebiyle Eba destek noktasına gidemeyen öğrencilere laptop } \\
\text { desteği sağladık. Öğretmenler öğrencilerle telefon ve whatsapp } \\
\text { grupları üzerinden iletişim kurarak yardımcı olmaya } \\
\text { çalıştık"K1"Öğrencilerimizi çevremizde bulunan eba destek } \\
\text { noktalarına yönlendirirken daha çok öğrencimizin kullana- } \\
\text { bileceği şekilde planlamalar yapıldı"K2 }\end{array}$ & $\begin{array}{l}\text { EBA DESTEK NOK- } \\
\text { TASI } \\
\text { YÖNLENDİRMESİ }\end{array}$ & 5 \\
\hline $\begin{array}{l}\text { UZAKTAN } \\
\text { EĞİTIME } \\
\text { KATILIM } \\
\text { PROBLEM- } \\
\text { LERİ }\end{array}$ & $\begin{array}{l}\text { "Öğretmenlerimizden derslere katılmayan öğrencileri tespit et- } \\
\text { melerini istedik. Gelen listedeki öğrencilerin velileri ile derslere } \\
\text { neden katılamadıkları konusunda bilgi istedik. İnterneti olan da } \\
\text { bağlatabilecek olanlara bilgisayar laboratuvarından ödünç bilgi- } \\
\text { sayar verdik. Bakanlığın ücretsiz verdiği internet hakkında bilgi } \\
\text { vererek kullanmalarını sağladık. Telefon görüşmesi, SMS ve } \\
\text { whatsapp grupları en çok kullandığımız iletişim yolları"K3 }\end{array}$ & $\begin{array}{l}\text { BAKANLIK } \\
\text { YARDIMLARINA } \\
\text { BAŞVURU }\end{array}$ & 7 \\
\hline $\begin{array}{l}\text { UZAKTAN } \\
\text { EĞITIME } \\
\text { KATILIM } \\
\text { PROBLEM- } \\
\text { LERİ }\end{array}$ & $\begin{array}{l}\text { “Öncelikle internet ağı tablet telefon sahibi olmayan öğrenciler } \\
\text { tespit edildi.. Yine kendi imkanlarımızla idare ve } \\
\text { öğretmenler olarak ihtiyaç sahibi öğrencilere destek verildi”K8 }\end{array}$ & $\begin{array}{l}\text { İDARE-ÖĞRETMEN } \\
\text { İŞBİRLİĞİ }\end{array}$ & 3 \\
\hline
\end{tabular}

Tablo 5 incelendiğinde görüşme yapılan okul yöneticilerden yedi tanesi öğrencilere teknik destek sağlamak için bakanlık yardımlarına başvurulduğunu ifade etmiştir. İnterneti olmayan veya internete erişim konusunda sıkıntı yaşayan öğrenciler için yöneticilerin bir kısmı “Öğrencileri eba destek noktasına yönlendirdik. Fiziksel engeli sebebiyle EBA (Eğitim Bilişim Ağı) destek noktasına gidemeyen öğrencilere laptop desteği sağladık. Öğretmenler öğrencilerle telefon ve whatsapp grupları üzerinden iletişim kurarak yardımcı olmaya çalıştık" K1

“Öğretmenlerimizden derslere katılmayan öğrencileri tespit etmelerini istedik. Gelen listedeki öğrencilerin velileri ile derslere neden katılamadıkları konusunda bilgi istedik. İnterneti olan da bağlatabilecek olanlara bilgisayar 
laboratuvarından ödünç bilgisayar verdik. Bakanlığın ücretsiz verdiği internet hakkında bilgi vererek kullanmalarını sağladık. Telefon görüşmesi, SMS ve whatsapp grupları en çok kullandığımız iletişim yollarıdır" K3, K5

"Öğrenci ve velilerle telefonlar ve mesajlaşma sistemiyle iletişim sağladık ve hala daha devam ediyoruz. Teknik desteğe ihtiyacı olan öğrencileri belirledik acil olanlara okul bilgisayarından faydalandırdık. Diğerlerini de ilgili yerlere bildirip yardım almalarını sağladık"K13

“İnternet, telefon veya tableti olmayan öğrenciler ivedilikle tespit edildi ve il milli eğitime bildirildi. Onlar için gerekli yardımlar yapıldı"K11

"İnternet imkânı olmayan öğrencileri arayarak ya da SMS yoluyla iletişime geçilebilir. Bu konuda okul yönetiminin yapabileceği en önemli şey eksiği bulunan öğrencilerin tespitini yapıp, sorunun çözülmesi için yetkilileri bilgilendirmektir" K5

“Öğretmenlerle iş birliği yaparak ihtiyacı olan öğrenciler belirlendi ve ilgili kurumlara (il milli eğitim) bildirildi"K7

Son olarak ta "İl ve ilçelerde açllan eba destek noktaları bu konuda bize destek sağladı. Genelde whatsapp grupları ve telefonla iletişime geçildi" K6 şeklinde yaptıkları işlemleri anlatmışlardır.

\section{Beşinci Temaya İlişkin Bulgular}

Tablo 6. “Okulda gerçekleşebilecek bulaş riskini göze alamayan veliler ile ilgili krize müdahale .

\begin{tabular}{|c|c|c|c|}
\hline Tema & Katılımcılar & kod & $\mathbf{n}$ \\
\hline $\begin{array}{l}\text { Yüz Yüze Eği- } \\
\text { time Katılım } \\
\text { Tunaği }\end{array}$ & $\begin{array}{l}\text { "Veliyi okula çağırır okulda alınan önlemleri gösterir, amacımızın önce- } \\
\text { likle çocuklarının sağlığı ve eğitimi olduğunu anlatırım. Sağlıklı bir } \\
\text { eğitim ortamının sağlanması için velilere görev düştüğünü evde } \\
\text { dışarıda kendilerinin de önlem alması gerektiğini ciddiyetini anlamları } \\
\text { için bu taahhütnamelerin önemli olduğunu eğer o imzalanmayacaksa } \\
\text { öğrencilerini okula alamayacağımı söylerim" } \\
\text { "Mevzuata bakarım öğrenciyi veli imzası olmadan almam gerektiğini } \\
\text { söyleyen bir ifade varsa ona göre davranırım"K10 }\end{array}$ & $\begin{array}{l}\text { MEVZUATI UY- } \\
\text { GULAMA }\end{array}$ & 5 \\
\hline $\begin{array}{l}\text { Yüz Yüze Ĕ̆i- } \\
\text { time Katılım Tu- } \\
\text { tanaği }\end{array}$ & $\begin{array}{l}\text { “Okulumuzun risk faktörü olarak görülmesini engelleyip güvenli or- } \\
\text { tamı yarattıktan sonra velimiz zaten bize inanacak ve imzayı atacaktır } \\
\text { ikna edeceğime inanıorum"K9 }\end{array}$ & $\begin{array}{l}\text { İKNA ETME ve } \\
\text { REHBERLIKK }\end{array}$ & 3 \\
\hline $\begin{array}{l}\text { Yüz Yüze Ĕ̆i- } \\
\text { time Katılım Tu- } \\
\text { tanaği }\end{array}$ & $\begin{array}{l}\text { "Bakanlığın ilgili yazısını öğrenci velisine tebliğ ederim, ikna etme yönt- } \\
\text { emlerini kullanırım yine de ikna olmazsa tutanak tutarak sorumluluğu } \\
\text { alırım"K4“Bu tutanağı imzalamadığına dair bir tutanak hazırlar sınıf } \\
\text { öğretmeniyle beraber imzalarım”K7 }\end{array}$ & $\begin{array}{l}\text { TUTANAKLA } \\
\text { SORUMLULUK } \\
\text { ALIP ALMAMA }\end{array}$ & 5 \\
\hline $\begin{array}{l}\text { Yüz Yüze Ĕgi- } \\
\text { time Katılım Tu- } \\
\text { tanaği }\end{array}$ & $\begin{array}{l}\text { “Sorumluluğu üstüme almak istemem, resmi yerlerden yazı isterim ve } \\
\text { ona göre öğrenciyi okula kabul ederim"K12 }\end{array}$ & $\begin{array}{l}\text { ÜST MAKAMA } \\
\text { SEVKETME }\end{array}$ & 2 \\
\hline
\end{tabular}


Tablo 6 incelendiğinde altıncı sorumuz evrak imzalamakla alakalı bir soru olmuştur. Resmi bir evrak söz konusu olduğunda milli eğitime bağlı okullarda yöneticilik yapan okul müdürlerinin birçoğunun mevzuat konusuna önem verdikleri görülmektedir. Örneğin katılımcılar "Yapılan uygulamanın bakanlığın zorunlu bir uygulaması olduğunu belirtir; evrağı imzalamadan çocuğunu okula gönderemeyeceğini net bir şekilde ifade ederek eğitime uzaktan devam etmekle, tebliğ edilen tutanağı imzalaması arasında bir seçeneği seçmesini söylerim" K2, K5, K10 şeklinde kendini ifade etmişlerdir. Birçok yönetici de tutanak tutarak sorumluluğu almama konusunda israrc1 davranmışlardır. Görüşü alınan yöneticilerden bir tanesi “Veliye okul rehberlik servisiyle beraber bunun neden gerekli olduğuna dair bilgi verilir ve imzalamayabileceğini ve imzalamadığı takdirde çocuğunun uzaktan eğitimle okula devam edebileceği konusunda bilgi verilir. Karar veliye bırakılır" K1

Bir başka katılımcı "Yapılan uygulamanın bakanlığın zorunlu bir uygulaması olduğunu belirtir; evrakı imzalamadan çocuğunu okula gönderemeyeceğini net bir şekilde ifade ederek eğitime uzaktan devam etmekle, tebliğ edilen tutanağı imzalaması arasında bir seçeneği seçmesini söylerim" K2

“Bu noktada öğrenci velisine bakanlığın yaptığı uygulama tekrar tekrar izah edilir. Öğrencinin okula gelebilmesi için belgeyi imzalaması gerektiği ifade edilir. Konunun ehemmiyetinden ötürü idarenin inisiyatif alamayacağ ancak gerekli mecralardan (il-ilçe milli eğitim gibi) görüş alınabileceği söylenir" diyerek görüşlerini bildirmişlerdir. K6

Aynı zamanda sorumluluğu üzerine almakta çekinmeyen birkaç tane okul yöneticisi de görülmüştür ve "İdareci olarak öğrenci okuldan uzak kalmasin diye kabul ederdim"K11

"Veli ikna yöntemini kullanırım, mevzuata bakarım, eğer yine çözemezsem tutanak tutarım ve öğrencinin eğitim hakkı elinden alınamaz diye okula kabul ederim"K15

“Bakanlığın ilgili yazısını öğrenci velisine tebliğ ederim, ikna etme yöntemlerini kullanırım yine de ikna olmazsa tutanak tutarak sorumluluğu alırım" diyerek fikirlerini ifade etmişlerdir. K8 


\section{Altıncı Temaya İlişkin Bulgular}

Tablo 7. Pansiyonlu bir okulda idarecisiniz ve pandemi döneminde 12.sinflar destekleme kurslarn için okula geldiler ve yurtta kalıyorlar. Başka bir okul idarecisi ise riske girmek istememiş ve yurdunu kendi öğrencileri için açmamış. 5 öğrenci açıkta kalmış. Milli ĕgitim müdürü sizi arayarak o öğrencileri sizin yurda almanızı istiyor. Ancak siz de kendi öğrencilerinizi riske atmak istemiyorsunuz diğer taraftan da üstünüze bir şey diyemiyorsunuz. Bu sorunu nasıl çözersiniz?

\begin{tabular}{|c|c|c|c|}
\hline TEMA & KATILIMCILAR & KOD & $\mathbf{n}$ \\
\hline \multirow[t]{3}{*}{$\begin{array}{l}\text { PANSIYYONA } \\
\text { YABANCI ÖĞ- } \\
\text { RENCİ KABULÜ }\end{array}$} & $\begin{array}{l}\text { "Bu durumda ilk olarak mevzuata bakarım. Ardından öğren- } \\
\text { cileri mağdur etmemek adına test yaptırmalarını isterim test } \\
\text { sonuçları çıana kadar da diğer öğrencilerden uzak odalara } \\
\text { çkmamaları koşuluyla yerleştiririm"K6 } \\
\text { "Pansiyon mevzuatı öğrenciyi kabul edebilirsin diyorsa evet } \\
\text { kabul ederim. Kabul edemeyecek konumda kalırsam da öğ- } \\
\text { rencilerin mağdur olmamaları için elimden geleni yapar- } \\
\text { dım"K14 }\end{array}$ & $\begin{array}{l}\text { MEVZUATI } \\
\text { GULARIM }\end{array}$ & 5 \\
\hline & $\begin{array}{l}\text { "Hiçbir öğrencinin mağduriyet yaşamaması için kabul ederim } \\
\text { fakat o öğrencileri ayrı odalarda muhafaza ederim"K15 }\end{array}$ & $\begin{array}{l}\text { SORUMLULUK } \\
\text { ALMA ve KABUL }\end{array}$ & 8 \\
\hline & $\begin{array}{l}\text { "Il milli eğitim müdürlüğünden durumla alakalı resmi yazı ta- } \\
\text { lep ederim. Eğer yazı almazsam ben de sorumluluk almam"K7 }\end{array}$ & $\begin{array}{l}\text { RISKK ALMAMA } \\
\text { RET }\end{array}$ & 2 \\
\hline
\end{tabular}

Tablo 7 ve son soru ve yöneticilerin verdikleri yantlar incelendiğinde “Öğrencilerin hakkı olan eğitimden uzak kalmaması için yönetmeliğe aksi bir durum oluşturmuyorsa öğrencileri pansiyona alırım. Toplu kullanım alanlarını öğrenci sayısına göre saatlere bölerek aynı anda ortamda bulunan öğrenci sayısını en aza indirmeye çalışırım” K2

"Bu durumda ilk olarak mevzuata bakarım. Ardından öğrencileri mağdur etmemek adına test yaptırmalarını isterim test sonuçları çıkana kadar da diğer öğrencilerden uzak odalara çıkmamaları koşuluyla yerleştiririm" $\mathrm{K} 6$.

"Eğitime bakış açısı olarak firsat eşitliğini yaratmak idareci olarak görevimdir. Gelen öğrencileri kabul ederim. Benim öğrencilerimi riske atmamak içinde onları uzak ve ayrı odalara alırım. Gelen öğrencinin velileri ile görüşerek hastalık geçmişlerini ister sonra test yaptırmalarını isterim. Kısacası risk alırım ama kendi öğrencimi de korurum. Eğitim hakkına fırsat veririm" $\mathrm{K} 9$.

"Pansiyona öğrenci kabul etmek biraz tehlike arz eden bir durum fakat öğrenciyi de ortada bırakmak olmaz bu nedenle diğer öğrencileri riske atmayacak şekilde kabul ederim"K13. 
Okul müdürlerinin bazıları mevzuata bakar ona göre karar veririm diyerek düşüncesini söylemiştir. Düşüncelerini de şu sözlerle ifade etmişlerdir;

"Pansiyon yönetmeliğine ve mevzuata bakarım ona göre işlem yaparım" K12.

"Şu an pansiyonlu bir okulda görevli değilim ama eğer olsaydım mevzuata bakar ona göre davranırdım". K1

\section{Sonuç, Tartışma ve Öneriler}

$\mathrm{Bu}$ bölümde araştırma verilerinin yorumlanmasıyla ulaşılan sonuçlar ve bu sonuçlara dayalı geliştirilen önerilere yer verilmiştir.

\section{Sonuç ve Tartışma}

$\mathrm{Bu}$ çalışmanın amacı son bir yıldır yaşanan Covid-19 pandemisinde okul yöneticilerinin kriz yönetim stratejilerinin araştırılmasıdır. Aynı zamanda yöneticiler bu süreci nasıl yönetiyor bunu ortaya koymak amaçlanmıştır. Benzer çalışmalara bakıldığında okullarda meydana gelen kriz yönetiminde en büyük sorumluluk okul yöneticilerine düşmektedir. Böyle durumlar incelendiğinde müdürlerin kriz durumlarından çıkmak için uygulayacakları yöntemleri önceden saptayarak krize engel olamasalar bile zararı ez az seviyeye düşürmeleri gerektiği görülmüştür.

Argon ve Zafer (2009) çalışmalarında eğitim örgütlerinde en önemli unsurun iletişim olduğu vurgulamış, öğrencisi, velisi, öğretmeni, çalışanı ile okulların en yoğun iletişimin olduğu yerler olduğu ifade etmişlerdir. Bu nedenle okulların eğitim sisteminin önemli bir parçası olduğu ve beraber içinde yaşadığı topluma göre daha düzenli olması gerektiği belirtilmiştir. Aynı şekilde bu çalışmada da iletişimle benzerlik gösteren motivasyon kavramı irdelenmiştir. Okullar öğrencinin, öğretmenin, çalışanların günlerinin çok önemli bir kısmının geçirildiği yerler olmakla beraber çalışanların motivasyonlarının da iyi düzeyde olması gerektiği özellikle kurum kültürü açısından da önemli olduğu ifade edilmiştir. Yine benzer bir çalışmada ortaya çıkan kriz durumlarına müdahaleleri irdelendiğinde katılımcıların çoğu krizi çözmek için ilk olarak toplantı yapma ve soruşturma açma gibi yöntemleri kullandıkları görülmüştür (Döş ve Cömert, 2012). Bu çalışmaya zıt olarak 
araştırmamızda kriz meydana geldikten sonra ortaya çıkan çatışma durumunu çözmek adına daha çok iş birliği ve uzlaşma yöntemlerinin tercih edildiği görülmüştür.

Bir başka çalışmada ise bir okul yöneticisinin kararları, eylemleri birçok aileyi ve öğrenciyi hatta toplumun çoğunluğunu etkileyeceğinden dolayı özellikle kriz zamanlarında okul yöneticilerinin nasıl bir eğitim lideri olduğunu ve krizi nasıl yönettiğini ortaya koymak önemli olduğu (Lawrence, Kajs, 2009). Ve araştırmanın sonucunda kamu okullarında çalışan ilkokul yöneticilerinin kriz yönetme becerilerinin orta düzeyde olduğu görülmüştür. Bu çalışmaya benzer olarak çalışmamızda okul yöneticilerinin kriz ve çatışma çözerken daha çok yapıcı ve uyum sağlayıcı roller ortaya koydukları gözlemlenmiştir.

Bulgular değerlendirildiğinde ortaya çıkan kriz durumlarında okul yöneticilerinin çatışma çözme için kullandıkları strateji ve yöntemler konusunda araştırmaya katılan katılımcların çoğunluğu sorun çözme ve iş birliği yaklaşımını tercih ettiklerini ifade etmişlerdir. Katılımcıların bir kısmı da kurum kültürünün öneminden bahsedip çatışma çözme yöntemi olarak arabuluculuk ve yumuşatma yöntemini kullandıklarını ifade etmişlerdir.

Okul yöneticilerine kullandıkları motivasyon yöntemleri sorulduğunda katılımclar prim, maaş artı̧ı gibi maddi ödülleri vermeye yetkilerinin olmadığını ancak manevi olarak daha çok övgü, yapıcı eleştiri ve çalışma koşullarının iyileştirilmesi gibi yöntemleri tercih ettiklerini söylemişlerdir. Çalışma koşullarının iyileştirilmesi kısmında ise daha çok uygun ders planı hazırlama ve nöbet günlerini öğretmenin isteğine göre ayarlama gibi örnekler verilmiştir. Zaten zor koşullarda çalışan öğretmenlere onlara yardımcı olacak çözümler getirip motivasyonlarını artırmak yerinde olacaktır.

Covid-19 pandemi döneminde tüm dünya ile beraber ülkemizde de eğitime ara verildi ve öğrenciler okuldan ve yüz yüze eğitimden uzak kaldılar. Bu öğrencilerin ruh sağlığını korumak, onlara destek olmak, hatta hastalığı geçirmiş öğrencilere karşı önyargıya karşı nasıl davranacakları konusunda yöneticiler daha çok rehberlik servisinden hatta yetkili sağlik kuruluşlarından yardım almanın çok uygun olacağını belirtmişlerdir. Böyle sağlıkla alakalı üstesinden gelemeyeceğimiz durumlarda alanında uzman kişilerden destek almak yapılacak en uygun davranışlardandır. 
Pandemi dolayısıyla okullara ara verildiğinden bu dönemde uzaktan eğitim sürecine geçilmiştir. Uzaktan eğitim aslında eskiden beri üniversite seviyesinde kullanılmaktadır ancak bütün eğitim kademelerinde kullanımı ilk kez karşımıza çıkmaktadır. Uzaktan eğitim öğrenen ile öğretenin farklı yer ve zamanlarda olduğu iletişimlerinin de elektronik ortamda gerçekleştiği bir öğretim şeklidir (Aydın, 2005). Uzaktan eğitimin insanlığa sağladığı faydaları kadar ona ulaşmada bazı zorluklar yaşanmaktadır. Bu zorluklara karşı oku yöneticilerinin ne yaptıkları sorusu yöneltilmiş ve alınan cevaplarda çoğunluğun bakanlıktan ve il milli eğitim müdürlüklerinden yardım aldıkları tespit edilmiştir. Bazı yöneticilerin ise okul olarak kendi imkanları ile teknik desteğe ihtiyacı olan öğrencilere katkı sağladığı görülmüştür. Burada öğretmenlik mesleğinin sadece ders anlatmak olmadığını aslında gönülden ve vicdanen yapıldığını ifade etmek gerekir. Bu sebeptendir ki aslına birçok öğretmen ve yönetici bu süreçte elini taşın altına koyarak öğrencilere her durum için yardım etmek için ellerinden geleni yapmış oldukları görülmüştür.

Yine pandemi döneminde bir ara okullar açlmıştır. O dönemde okula öğrenci kabulü konusunda velilere sorumluluğu kabul ettiklerine dair bir tutanak imzalatmak zorunda kaldıklarında velinin bu durumu kabul etmek istemediği bir durumda kaldıklarında ne yapacakları sorulmuştur. Okul yöneticilerinin birçoğu mevzuatı uygulama ve tutanakla sorumluluk almama yolunu tercih etmişlerdir. Bir yönetici olarak aslında yapılan işlem yani mevzuatı uygulamak doğru bir davranıştır hele ki böyle zor bir hastalık sürecinde hem kendini zora sokmamak hem de kuralları uygulamak doğru bir yol olabilir. Aynı şekilde pansiyonlu bir okulda görev yaptıkları ve pansiyona kendi öğrencileri dışında bir öğrenciyi almak durumunda kaldıklarında ne yapacakları sorulduğunda yine mevzuat ve kurallara bakacaklarını belirtmişlerdir. Ancak bu konuda bazı yöneticiler öğrencileri dışarda bırakmamak ve mağdur etmemek adına öğrenciyi yurda kabul edeceklerini ifade etmişlerdir. Fakat burada pansiyonda kalan diğer öğrencileri riske atmamak için yeni gelenleri ayrı odalarda saklayacaklarını söylemişlerdir.

Sonuç olarak krizler aniden ve beklenmeyen zamanlarda meydana geldiği için her daim örgütlerin varlığını ve hedeflerini tehdit eden durum olmuştur. Kriz anında, örgütlerin iyi bir biçimde yönetilmesi, olumsuz durumdan hızla çıkılmasını kolaylaştıracaktır. Okul yöneticisinin karar ve davranışları, öğrencilerin, ailelerin, öğretmenlerin, okuldaki diğer çalışanların ve 
toplumdaki diğer insanları hayatlarını etkileyeceğinden ötürü bu belirsiz durumlarda, özellikle kriz gibi zor zamanlarda okul yöneticisinin nasıl bir lideri olduğunu ve kriz durumlarını nasıl yönettiğini ortaya koymak önemlidir. Kriz dönemlerinde, örgütler açısından hem tehditler hem de firsatlar bulunmaktadır. Bu nedenle örgüt yöneticileri, karşılaşılan kriz durumunu fırsat bilerek örgütün belli kazanımlar elde etmesi için gerekli çabayı göstermelidir. Okullar da her örgüt gibi krizlerden olumsuz yönde etkilenmektedirler. Ancak her ne kadar olumsuz etkilenme psikolojik çökme gibi etkenler olsa da okullar ve okul yöneticileri bu krizlerden tecrübe de sağlamaktadırlar.

\section{Öneriler}

Çalışma neticesinde aşağıdaki önerilerde bulunulabilir: Okullarda bundan sonra meydana gelebilecek krizler yöneticiler tarafından belirlenebilir ve çözümlere ilişkin ön çalışmalar yapılabilir. Okulların bünyelerinde oluşturulan kriz ekiplerinin verimli çalışmaları açısından öğretmenlere bu yönde hizmet içi eğitimler verilebilir. Okul yöneticileri tarafında önceden uygulanan ve iyi sonuçlanan yöntem ve stratejilerin kullanılması yönünde gerekli yönlendirmeler yapılabilir. Tüm paydaşların özellikle öğrenci merkezli yaşanılan krizlerin daha verimli çözülebilmesi için veliler de işin içine katılabilir ve eğitilerek bilgilendirilebilirler. Kriz yönetim becerileri bakımından bu araştırma daha kapsamlı hale getirilerek velilere de uygulanabilir. Öğrencilerin de kriz yönetim becerileri bakımından okul yöneticilerini değerlendirecekleri çalışma yürütülebilir. Okul yöneticilerinin çatışma yönetimi konusunda başka faktörler incelenebilir örnek olarak veli ile çatışma, personel ile çatışma.Bundan sonra bu konuyu çalışmak isteyen araştırmacilar da okul yöneticilerinin akabinde öğretmen konusunu çalışabilirler. Farklı bölgelerdeki okullarda görev alan okul yöneticilerinin kriz yönetim becerileri öğretmen, öğrenci ve veli görüşlerine dayalı olarak karşılaştıılmalı yürütülebilir. Kriz yönetimi bakımından okullar tek tek irdelenerek her okul için kriz yönetim bilgi düzeyi belirlenip bu yönde gelişimleri ve ilerlemeleri sağlanabilir. Okul müdürlerinin çatışma yönetimi alanında yetersizlikleri üzerinde çalışmalar yoğunlaştırılarak yetersizliklerini giderme ve alternatif çözüm yolları önerilebilir. 


\title{
EXTENDED ABSTRACT \\ The Schools Principal's Methods and Strategies Used in the Distance Education Period
}

\author{
* \\ Tuba Aydın Güngör- Mehtap Yılmaz \\ Artvin University
}

Organization is an agreement and cooperation that people put forward for some goals and values. While organizations want to achieve the goals they have determined, they may sometimes encounter undesirable and unexpected negativities. Sometimes, the crises that arise within the organization cause the organization to stall and the daily routine to be disrupted. Strong, determined and effective leadership is required at the time of crisis. The leader should be confident and be able to eliminate the existing crisis situation more powerfully by determining new strategies. The time when the leadership characteristics and competencies of the managers are most needed is the time of crisis in the organization because a good manager has to successfully overcome the crisis process under his own control. At such times, the existing strategy of the organization may be insufficient and studies can be made to follow a new path. The important thing at the time of the crisis is not to escape from the situation or to resolve the crisis situation, but to prevent it from coming out before the crisis emerges or to turn the existing crisis situation into an advantage. The factors that trigger the crisis often predict themselves. The crisis manager may fall into negativity in this process and may not be able to resolve the situation. However, it can also successfully steer the crisis. The important thing is not to get involved in the negative mood of the crisis situation. It is based on the determination of the elements that can create the crisis in the modern management approach. The virus, which was reported to be seen in Wuhan, China on December 29, 2019, which caused pneumonia and upper respiratory tract infections in an unknown way and resulted in death, was named as Covid-19 by the World Health Organization and announced to the whole world. In our country, it emerged in mid-March 2020 and caused crises in various fields. School administrators, who may emerge during the Covid-19 pandemic process; along with managing the crisis 
between parents, students and teachers, it is necessary to take measures to ensure that education continues in the same way. Being able to manage the crisis caused by this epidemic, which affects the whole world, also brings out the leader managers. From this point, the aim of this study is to research the schools principal's methods and strategies of conflict solving during the crisis periods and also to reveal how school principals manage the process during the crisis caused by the covid-19 pandemic. This study is a qualitative research research which has been designed as a phenomenological pattern from qualitative research types. Semi-structured interview form was used for gathering data since qualitative research method was used in the study because the research in small groups provides an in-depth and detailed perspective to the researcher. The study group of the research consists of 15 school administrators working in Artvin. In order to ensure maximum diversity, administrators from the secondary and high school levels were selected. Interviews were conducted to collect qualitative data. data was analysed with content analysis from qualitative data analysis methods. At the end of the study, as a result, crises have always been a situation that threatens the existence and goals of organizations because they occur suddenly and unexpectedly. In the time of crisis, good management of organizations will make it easier to get out of the negative situation quickly. Since the school administrator's decisions and behaviors will affect the lives of students, families, teachers, other employees in the school and other people in the society, it is important to reveal what kind of a leader the school administrator is and how he manages crisis situations in these uncertain situations, especially in difficult times such as crisis. When the findings were evaluated, the majority of the participants in the research stated that they preferred the problem solving and cooperation approach regarding the strategies and methods used by school administrators for conflict resolution in crisis situations. Some of the participants also mentioned the importance of corporate culture and stated that they used mediation and moderation as a conflict resolution method. As a result of the study, the following suggestions can be made: The crises that may occur in the schools can be determined by the administrators and preliminary studies can be made regarding the solutions. Teachers can be given in-service training in this direction in terms of the efficient work of the crisis teams formed within the schools. Necessary 
guidance can be given by school administrators for the use of methods and strategies that have been applied before and that have resulted in good results.

\section{Kaynakça / References}

Akdağ, M. ve Taşdemir, E. (2006). Krizden çıkmanın yolları: Etkin bir kriz iletişimi. Selçuk İletişim, 4(2), 141-157.

Akdemir, A. (1997). Yönetim düşüncesindeki dönüşümler ve dönüştürücü lider profili. 21. Yüzyılda Liderlik Sempozyumu Bildiriler Kitabı, 1, 142-148.

Aksoy, H. H. ve Aksoy, N. (2002). Okullarda krize müdahale planlaması. Ankara Üniversitesi, Eğitim Bilimleri Fakültesi Dergisi, 36(1-2), 37-49.

Akyavuz, E. K. ve Çakın, M. (2020). Covid-19 Salgınının Eğitime EtkisiKonusunda Okul Yöneticilerinin Görüşleri. Electronic Turkish Studies, 15(4), 723-737.

Ali, A. ve Deveci, S. (2009). İköğretim okulu müdürlerinin kriz yönetimi becerileri. Education Sciences, 4(2), 448-464.

Altınbaş, O. (2020). Okul gelişiminde yöneticilerin marka ve kriz yönetim becerilerinin değerlendirilmesi. Doktora Tezi. Yakın Doğu Üniversitesi, Eğitim Bilimleri Enstitüsü, Eğitim Yönetimi, Eğitim Denetimi, Ekonomisi ve Planlaması Ana Bilim Dalı, Lefkoşa.

Augustıne, N. R. (2000). Önlemeye çalıştığını krizi yönetmek. Kriz yönetimi. Salim Atay (Çev). İstanbul: BZD Yayıncilık.

Aydın, C.H. (2005). Açı ve uzaktan öğrenmede kullanılan basılı materyallerdeki anlatım biçimine ilişkin öğrenen tercihleri. Anadolu Üniversitesi Sosyal Bilimler Dergisi, 5(1), 131-147.

Aydın, M. (1994). Eğitim yönetimi (4. baskı). Ankara: Hatipoğlu Yayınevi.

Barutçugil, İ. (2006). Yöneticinin yönetimi. İstanbul: Kariyer Yayınları.

Bingöl, E. (2014). İlk ve ortaokul yöneticilerinin öğretimsel liderlik özelliklerinin öğretmenlerin motivasyon düzeyi ve problem çözme becerilerine olan etkisi. Master's thesis. Hasan Kalyoncu Üniversitesi, Sosyal Bilimler Enstitüsü İşletme Yönetimi Anabilimdali İşletme Bilim Dali, Gaziantep.

Booth, A. S. (1993). Crisis management strategy. Competition and Change in Modern Enterprises. London: Routledge Publishing.

Bozkurt, Ö., Ergun, T. ve Sezen, S. (1998). Кати yönetimi sözlüğü. Ankara: Türkiye ve Orta Doğu Amme İdaresi EnstitüsüYayınları, Yayın No: 283.

Brewton, C. (1987). Managing a crisis: A model for the lodging industry. The Cornell HRA Quarterly, 28(3), 10-15. 
Bursalığlu, Z. (1994). Okul yönetiminde yeni yapı ve davranış. Ankara: Pegem Yayincilik.

Can H., Azizoğlu, Ö.A. ve Aydın, E.M. (2011). Organizasyon ve yönetim. (8.Baskı). Siyasal Kitabevi.

Can, H. (1994). Organizasyon ve yönetim. Ankara: Siyasal Kitap Evi.

Cömert, M. (2012). Illköğretim okullarında kriz yönetimi hakkında okul müdürlerinin görüşleri. Mustafa Kemal Üniversitesi Sosyal Bilimler Enstitüsü Dergisi, 9(20), 329-346.

Dulkadir, B. (2017). Kriz yönetim planının işletmelerde kriz dönemleri ve yönetici davranışlarına olan etkileri. Social Sciences, 11, 223-240.

Ekinci, H. ve Ferit, İ. (2006). Kriz yönetiminde insan kaynaklarına psikolojik desteğin önemi ve Kayseri tekstil sektöründe bir araştırma. Kocaeli Üniversitesi Sosyal Bilimler Dergisi, 12, 39-54.

Erdoğan, İ. (2005). Yeni bin yıla doğru Türk eğitim sistemi: Sorunlar ve çözümler (4. bask1). İstanbul: Sistem Yayıncilk.

Ersoy, F. (2016). Fenomenoloji. A. Saban ve A. Ersoy (Ed.). Eğitimde nitel araştırma içinde (s.51-105). Anı Yayınclik.

Fink, S.( 1986). Crisis management. New York: American Management Association.

Genç, N. (2013). Yönetim ve organizasyon: Çă̆daş sistemler ve yaklaşımlar. Seçkin Yayıncilik.

George, J. M. and Brief, A. P. (1996). Motivational agendas in the workplace: The effects of feelings on focus of attention and work motivation. Elsevier Science/JAI Press.

Hartoka, E. (2017). Okul yöneticilerinin çatışma çözme stilleri. Pamukkale Üniversitesi, Eğitim Bilimleri Enstitüsü, Eğitim Bilimleri Ana Bilim Dal.

Ilgar, L., (1996). Eğitim yönetimi, okul yönetimi, simf yönetimi. İstanbul: Beta.

İknur, M. (2014). Kamu İkokullarında Yöneticilerin Sergiledikleri Kriz Yönetimi Beceri Düzeylerine İlişkin Öğretmen Görüşleri. Yönetim Bilimleri Dergisi, 12(23), 209-235.

İnandı, Y. (2008). Resmi ilk ve ortaöğretim okulları müdürlerinin okullarındaki kriz durumlarına ilişkin yaklaşımlarının değerlendirilmesi. Dicle Üniversitesi Ziya Gökalp Ĕ̆itim Fakültesi Dergisi, 10, 36-55.

İnce, F. (2013). Verimliliği artırmada motivasyonun gücü. Yayımlanmamış Yüksek Lisans Tezi. Beykent Üniversitesi Lisansüsatü Eğitim Enstitüsü, Sosyoloji Ana Bilim Dalı, İstanbul.

Jones, M. and Paterson, L. (1992). Preventing chaos in times of crisis: A guide for school administrators. Los Alamitos, CA. Southwest Regional Lab. 
Kajs, L. T. and McCollum, D. L. (2009). Examining tolerance for ambiguity in the domain of educational leadership. Academy Of Educational Leadership Journal, 13(2), 1-16.

Karaağaç, T. (2013). Kriz yönetimi ve iletişim. İstanbul Üniversitesi Siyasal Bilgiler Fakültesi Dergisi, 49, 117-132.

Karadeveci, Z. B. (2004). Kriz ortamında turizm işletmelerinde risk yönetimi ve finansal kararlar. Yayınlanmamış Yüksek Lisans Tezi. Dokuz Eylül Üniversitesi, Sosyal Bilimler Enstitüsü, İzmir.

Karaköse, T. (2007). Örgütler ve kriz yönetimi. Akademik Bakış, 13, 1-15.

Karakuş, A. ve İnandl, Y. (2018). Ortaokul yöneticilerinin okullarında yaşanan kriz durumların yönetme becerilerinin incelenmesi. Mersin Üniversitesi Ĕ̆itim Fakültesi Dergisi, 14(2), 500-518.

Koçak, R. ve Eves, S. (2010). Okul yöneticilerinin iş doyumları ile problem çözme becerileri arasındaki ilişki. Uluslararası İnsan Bilimleri Dergisi, 7(1), 193-212.

Konak, M. ve Erdem, M. (2015). Öğretmenlerin görüşlerine göre ilkokul yöneticilerinin etik liderlik davranışlanı ile çatışma yönetme stratejileri arasındaki ilişki. Kuram ve Uygulamada Eğitim Yönetimi Dergisi, 21(1), 69-91.

Korkmaz, M. (2008). Okul müdürlerinin liderlik stilleri ile öğrenen örgüt özellikleri arasındaki ilişki üzerine nicel bir araştırma. Kuram ve Uygulamada Ĕ̆itim Yönetimi Dergisi, 53, 75-98.

Ögel, K., Tarı, I., Eke, C. Y., Danışmanları, P., Aksoy, A. ve Erol, B. (2006). Okullarda Suç Ve Şiddeti Önleme. İstanbul: Yeniden Yayınları.

Özdemir, T.A.(2002). İlköğretim okul müdürlerinin kriz yönetimi konusundaki koordinasyon yeterliliklerinin değerlendirilmesi. Yayınlanmamış Yüksek Lisans Tezi. Abant İzzet Baysal Üniv., Sosyal Bilimler Enstitüsü, Bolu.

Öztürk, E. ve Uzunkol, E. (2013). İlkokul Öğretmeni Motivasyon Ölçeğinin Psikometrik Özellikleri. Eğitimde Kuram ve Uygulama, 9(4), 421-435.

Öztürk, B. (2010). Kriz yönetimi ve örnek bir uygulama. (Yayımlanmamış yüksek lisans tezi). Yıldız Teknik üniversitesi, Fen Bilimleri Enstitüsü, Endüstri Mühendisliği Anabilim Dalı, İstanbul.

Patton, M. Q. (2014). Nitel araştırma ve değerlendirme yöntemleri (M. Bütün \& S. B. Demir, Çev. Ed.) Pegem Akademi.

Pearson, Christine M., and Clair, Judith A. (2008). Reframing Crisis Management, Crisis Management. London: Sage.

Peker, Ö. (2000). Etkili yönetim becerileri: öğrenilebilir ve geliştirilebilir. Yargı Yayınevi.

Pheng, L. S., Ho, David K.H. and Ann Y. S. (1999). Crisis management: A survey of prop erty development firms. Property Management, 17(3), 234. 
Sağlam, A ve Özsezer, S . (2015). Liselerde okul yönetimlerinin kriz yönetme becerilerine ilişkin öğretmen görüşleri. Electronic Journal of Education Sciences,4(7), 01-14.

Sayll, İ. (1992). Olağanüstü koşullarda krize müdahalenin yeri ve önemi. Kriz Dergisi, 1(1), 4-7.

Sayın, N. (2008). Ortaöğretim kurumlarnda kriz yönetimi stratejisinin incelenmesi (İstanbul İli Örneği). Marmara Üniversitesi, Eğitim Bilimleri Enstitüsü, İstanbul.

Sezgin, F. (2003). Kriz yönetimi. Kırgizistan-Türkiye Manas Üniversitesi Sosyal Bilimler Dergisi, 8, 181-195.

Sikich, G. W. (2002). All hazards crisis management pla-nning. logical management systems. Erişim adresi: https://cool. culturalheritage. org/byauth/sikich/allhz. Html (15.05. 2020).

Şimşek, Ş. (1999). Yönetim ve organizasyon. Ankara: Nobel Yayın Dağtım.

T.C. Anadolu Üniversitesi Yayını No: 2818 Açk öğretim Fakültesi Yayını No: 1776

Tikici, Ahmet. (2005). Örgütsel davranış boyutlarından seçmeler. Ankara: Nobel Yayın Dağitım.

Tutar, H. (2000). Kriz ve stres ortaminda yönetim. İstanbul: Hayat Yayıncilik.

Türk Dil Kurumu Sözlüğü (2014). tdk.gov.tr/index.php?option=com Erişim Tarihi: 14.11.2019.

Tüz, M. V. (2004). Kriz yönetimi: İşletmelerde uygulama için temel adımlar (3.baskı). İstanbul: Alfa Basım Yayım.

Ulutaş, S. (2010). Kriz yönetimi ve dönüşümcü liderlik. Yayınlanmamış yüksek lisans tezi. Dokuz Eylül Üniversitesi, Sosyal Bilimler Enstitüsü, İzmir.

Uslanmaz, A. (2004). Kriz yönetimi ve doğal afetlere hazırlk: Düzce deneyimi ve yeni bir model önerisi. Yayımlanmamış Yüksek Lisans Tezi. Abant İzzet Baysal Üniversitesi Sosyal Bilimler Enstitüsü, Bolu.

Ülgen, H. (1993). İşletmelerde organizasyon ilkeleri ve uygulaması. İstanbul: İşletme ve İktisadi Enstitüsü Yayın.

Warren, Richard C. (1996).The empty company: Morality and job security. Personel Review,25(6), 41-53.

Ylldırım, A. ve Şimşek, H. (2003). Sosyal bilimlerde nitel araştırma yöntemleri. Ankara: Seçkin yayıncllı.

Yılmaz, Ö.D., (2004). Turizm işletmelerinde kriz yönetimi ve konaklama işletmeleri yöneticilerinin krizlere ilişkin yaklaşımlarına yönelik bir araştırma. Yayınlanmamış Yüksek Lisans Tezi. Dokuz Eylül Üniversitesi. Sosyal Bilimler Enstitüsü, İzmir. 


\section{Kaynakça Bilgisi / Citation Information}

Aydın Güngör, T. ve Yılmaz, M. (2021). Okul yöneticilerinin uzaktan eğitim döneminde kullandıkları çatışma stratejileri ve yöntemleri. OPUS-Uluslararası Toplum Araştırmaları Dergisi, 18(41), 3583-3608. DOI: 10.26466/opus.941874. 